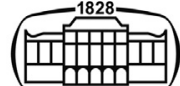

AKADÉMIAI KIADÓ

\title{
HPLC-UV method for quantification of favipiravir in pharmaceutical formulations
}

\section{IBRAHIM BULDUK* (1)}

\section{Acta Chromatographica}

33 (2021) 3, 209-215

DOl:

$10.1556 / 1326.2020 .00828$

(C) 2020 The Authors
Department of Chemistry, School of Health, Uşak University, 64200, Uşak, Turkey

Received: August 5, 2020 - Accepted: August 9, 2020

Published online: August 31, 2020

\section{REVIEW PAPER}

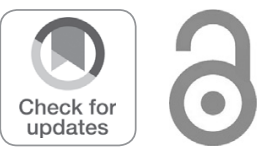

Corresponding author.

E-mail: ibrahim.bulduk@usak.edu.tr

\begin{abstract}
Favipiravir (FVP), a pyrazine analog, has shown antiviral activity against a wide variety of viruses. It is considered to be worth further investigation as a potential candidate drug for COVID-19. It is not officially available in any pharmacopoeia. A rapid, simple, precise, accurate, and isocratic high performance liquid chromatography (HPLC) method has been developed for routine quality control of favipiravir in pharmaceutical formulations. Separation was carried out by $\mathrm{C} 18$ column. The mobile phase was a mixture of $50 \mathrm{mM}$ potassium dihydrogen phosphate $(\mathrm{pH} \mathrm{2.3)}$ and acetonitrile (90:10, v/v) at a flow rate of $1 \mathrm{~mL} \mathrm{~min}^{-1}$. The ultraviolet (UV) detection and column temperature were $323 \mathrm{~nm}$, and $30{ }^{\circ} \mathrm{C}$, respectively. The run time was $15 \mathrm{~min}$ under these chromatographic conditions. Excellent linear relationship between peak area and favipiravir concentration in the range of 10-100 $\mathrm{gg} \mathrm{mL}^{-1}$ has been observed $\left(r^{2}, 0.9999\right)$. Developed method has been found to be sensitive (limits of detection and quantification were $1.20 \mu \mathrm{g} \mathrm{mL}^{-1}$ and $3.60 \mu \mathrm{g} \mathrm{mL}^{-1}$, respectively), precise (the interday and intraday relative standard deviation (RSD) values for peak area and retention time were less than 0.4 and $0.2 \%$, respectively), accurate (recovery, 99.19-100.17\%), specific and robust (\% RSD were less than 1.00, for system suitability parameters). Proposed method has been successfully applied for quantification of favipiravir in pharmaceutical formulations.
\end{abstract}

\section{KEYWORDS}

favipiravir, antiviral, HPLC, method, development, validation

\section{INTRODUCTION}

Chinese-borne coronavirus disease (COVID-19) spread rapidly and became an epidemic, affecting almost all countries and regions around the world. COVID-19 case death rate ranges from $1 \%$ to $7 \%$ according to the reports of World Health Organization (WHO). It caused all people in the world to change their lifestyle. It still threatens the entire World [1]. Since the outbreak of the COVID-19 began to affect the world, countries have implemented different treatment methods.

Active therapeutic alternatives are urgently needed as a rising COVID-19 pandemic and possible effects on global health [2]. Many medications such as chloroquine, arbidol, remdesivir, and favipiravir are currently undergoing clinical trials in several countries to assess their effectiveness and safety in treating coronavirus disease [3,4]. So far, there is no gold standard for the treatment of COVID-19 since there is not enough evidence [5].

Favipiravir (6-fluoro-3-hydroxypyrazine-2-carboxamide) is an analog of pyrazine (Fig. 1). Favipiravir (FVP) is an antiviral drug that was initially developed for influenza by Toyama Chemical. It selectively inhibits the RNA polymerase of RNA viruses, thus preventing viral reproduction. It displays antiviral activity against alpha-, filo-, bunya-, arena-, flavi-, and noroviruses $[6,7]$, as well as being active against the influenza virus.

After a pilot trial by Zhongnan Hospital of Wuhan University has found a better recovery rate in COVID-19 patients in the favipiravir group compared to the arbidol group [8], FVP is considered to be worth further investigation as a potential candidate drug for this disease. 
<smiles>NC(=O)c1nc(F)cnc1O</smiles>

Fig. 1. Chemical structure (favipiravir)

According to the literature search, there are two published high performance liquid chromatography (HPLC) methods for determining FVP assay and impurities in active pharmaceutical ingredients $[9,10]$. In both of these methods, a gradient HPLC mode was used for chromatographic separation and the run time was $60 \mathrm{~min}$. FVP is not officially available in any pharmacopoeia and there is still a need for validated HPLC methods to determine FVP in pharmaceutical formulations.

\section{EXPERIMENTAL}

\section{Chemicals}

Analytical grade chemicals were used without further purification in this study. Potassium dihydrogen phosphate (99.5-100.5\%, Sigma-Aldrich), ortho-phosphoric acid ( $\geq 85 \%$, Sigma-Aldrich), and HPLC-grade acetonitrile ( $\geq 99.9 \%$, Sigma-Aldrich) were used. Deionized water was purified by a Milli-Q system (Millipore) with conductivity lower than $18.2 \mu \mathrm{S} \mathrm{cm}^{-1}$. FVP bulk powder and tablets (favicovir, $200 \mathrm{mg}$ ) were obtained from Atabay Pharmaceuticals and Fine Chemicals Inc (Istanbul, Turkey).

\section{Stock standard solution}

One hundred milligram pure drug was accurately weighed, dissolved in about $30 \mathrm{~mL}$ of deionized water and transferred to a $100 \mathrm{~mL}$ volumetric flask. Then the volume was completed to $100 \mathrm{~mL}$ with deionized water to obtain $1 \mathrm{mg} \mathrm{mL}^{-1}$ of stock solution. The resulting stock solution was sonicated and filtered through a $0.45 \mu \mathrm{m}$ filter. The stock solution was further diluted with deionized water to obtain the required concentration of standard solutions $\left(10-100 \mu \mathrm{g} \mathrm{mL}^{-1}\right)$ before being injected into the system for analysis.

\section{Sample solution}

Ten FVP tablets were accurately weighed and transferred to a dry and clean mortar, then ground into a fine powder. Next, tablet powder equal to $250 \mathrm{mg}$ FVP was transferred to a volumetric flask of $250 \mathrm{~mL}$. About $100 \mathrm{~mL}$ deionized water was added and this flask was attached to a rotary shaker for $10 \mathrm{~min}$. to completely disperse the ingredients. The mixture was sonicated for $30 \mathrm{~min}$, diluted to volume with deionized water to give a solution containing $1,000 \mu \mathrm{g} \mathrm{mL}^{-1}$ and then filtered through a $0.45 \mu \mathrm{m}$ filter.

\section{Determination of $\lambda_{\max }$}

Standard solution ( $\left.40 \mu \mathrm{g} \mathrm{mL}^{-1}\right)$ was subjected to scanning between 200 and $800 \mathrm{~nm}$ on a ultraviolet (UV) spectrophotometer (Shimadzu UV-1800 spectrophotometer). $\lambda_{\max }$ was obtained from the UV spectrum of standard solution.

\section{Chromatographic conditions}

Chromatographic analysis was performed on a column of Inertsil ODS-3V C18 $(4.6 \mathrm{~mm} \times 250 \mathrm{~mm}, 5.0 \mu \mathrm{m})$. The mobile phase consisted of potassium dihydrogen phosphate $50 \mathrm{mM}(\mathrm{pH} 2.3)$ and acetonitrile (90:10, v/v). The mobile phase was filtered and degassed through a $0.45 \mu \mathrm{m}$ membrane filter before use and then pumped at a flow rate of $1 \mathrm{~mL} \mathrm{~min}{ }^{-1}$. The column has been thermostated at $30{ }^{\circ} \mathrm{C}$. The run time was 15 min under these conditions.

\section{Method validation}

The analytical method validation has been performed as per ICH guidelines of Validation of Analytical Procedure: Q2 (R1) $[11,12]$. The validation parameters such as system suitability, linearity, the limit of detection (LOD), the limit of quantification (LOQ), accuracy, specificity, precision, and robustness were addressed.

\section{Linearity}

Standard calibration has been prepared using six standard solutions within the concentration range of $10-100 \mu \mathrm{g} \mathrm{mL}^{-1}$. In optimized chromatographic conditions, each standard solution was chromatographed for $15 \mathrm{~min}$ three times. Least squares linear regression analysis of the average peak area versus concentration data were used to evaluate the linearity of the method.

\section{Specificity/selectivity}

Selectivity is the ability of the analytical method to produce a response for the analyte in the presence of other interference. The selectivity of the method was tested by comparing the chromatograms obtained for FVP standard, tablet, and

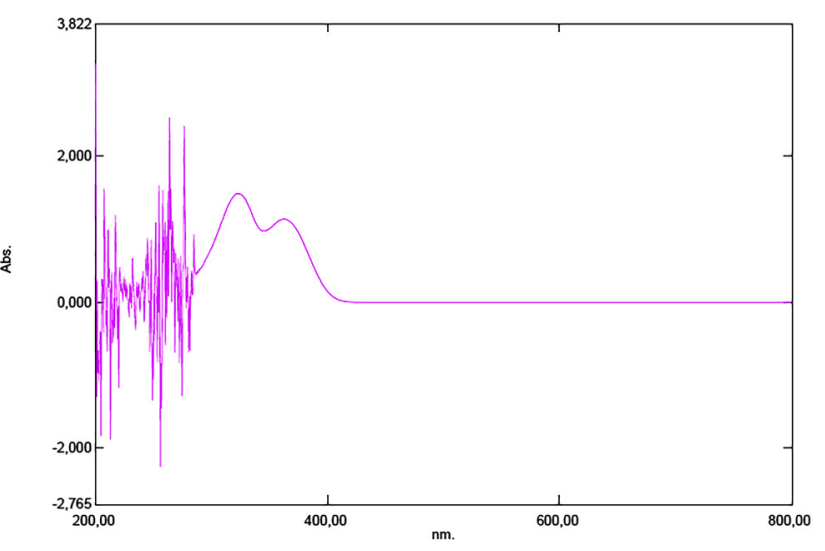

Fig. 2. UV spectrum (standard solution, $40 \mu \mathrm{g} \mathrm{mL}^{-1}$ ) 
blank solutions. The parameters retention time and tailing factor were calculated in order to prove that the method chosen was specific.

\section{Limit of detection and limit of quantification}

These values were determined using the standard error $(s)$ and slope of the regression line $(\mathrm{m})$ as shown in following equations:

$$
\begin{aligned}
& \text { LOD }=3.3 * \mathrm{~s} / \mathrm{m} \\
& \text { LOQ }=10 * \mathrm{~s} / \mathrm{m}
\end{aligned}
$$

\section{Precision}

Precision was analyzed by calculating variations of the method in intraday (repeatability performed by analyzing standard solution on the same day) and inter-day (repeatability carried out by analyzing standard solution on three different days). Precision study was performed by injecting six times of standard solution at three different concentrations, 20,40 , and $60 \mu \mathrm{g} \mathrm{mL}^{-1}$ on the same day and three consecutive days.

\section{Accuracy}

Recovery studies were conducted by the standard addition technique to confirm the accuracy of the proposed method. In this method, 80,100 and $120 \%$ of three different levels of pure drug were added to the previously analyzed sample solutions, and favipiravir recovery was calculated for each concentration.

\section{Robustness}

A robustness analysis was performed to determine the impact of minor yet systematic differences in chromatographic conditions. The modifications include different flow rates of the mobile phase $\left( \pm 0.1 \mathrm{~mL} \mathrm{~min}^{-1}\right)$, acetonitrile ratio in the mobile phase $( \pm 1 \%)$ and column temperatures $\left( \pm 2{ }^{\circ} \mathrm{C}\right)$. After each change, System suitability parameters were checked by injecting the sample solution into the chromatographic system and the results were compared with those under the original chromatographic conditions.

\section{Analysis of marketed formulations}

Four milliliter of above prepared sample solution has been transferred into a volumetric flask of $100 \mathrm{~mL}$ and filled the mark with deionized water to prepare at the concentration of $40 \mu \mathrm{g} \mathrm{mL}^{-1}$ sample solution. This sample solution was filtered using $0.45 \mu \mathrm{m}$ filter and then analyzed.

\section{Solution stability}

The stability of sample and standard solutions was monitored over a $24 \mathrm{~h}$ period. For this, standard and sample solutions were injected into the system at $8 \mathrm{~h}$ periods, and the peak area and retention time were evaluated. During the stability study, standard solutions have been stored at ambient temperature $\left(25^{\circ} \mathrm{C}\right)$ and protected from light.

\section{RESULT AND DISCUSSION}

\section{Determination of $\lambda_{\max }$}

The wavelength corresponding to maximum absorbance $\left(\lambda_{\text {max }}\right)$ was determined as $323 \mathrm{~nm}$ from the UV spectrum of standard solution (Fig. 2).

\section{Method development}

Several preliminary studies were conducted to optimize the chromatographic conditions for the quantification of FVP. Mobile phases consisting of several buffer systems were tried at the beginning of the study; they could not meet the required system parameters. Then only potassium dihydrogen phosphate buffer system was tested without using organic modifiers, long analysis times were obtained. Different acetonitrile solution ratios were investigated to obtain optimum conditions. The acetonitrile ratio was determined as $10 \%$ against $50 \mathrm{mM}$ potassium dihydrogen phosphate solution $(\mathrm{pH}=2.3$ ) due to the favipiravir peak being well shaped and symmetrical using this system. Eventually, it was found that the mobile phase consisting of $50 \mathrm{mM}$ potassium dihydrogen phosphate ( $\mathrm{pH}$ : 2.3 with ortho-phosphoric acid) and acetonitrile (90:10, v/v) provided stronger theoretical plates $(>2,000)$ and peak tailing factor $(<1.0)$. Mobile phase running at different flow rates (0.5-1.5 $\left.\mathrm{mL} \mathrm{min}^{-1}\right)$ and containing mixtures of organic solvents and phosphate buffers, with ionic strengths and $\mathrm{pH}$ ranges were tested. Collectively, the best chromatographic conditions were achieved using an isocratic mobile phase comprising $50 \mathrm{mM}$ potassium dihydrogen phosphate $(\mathrm{pH}=$ 2.3)-acetonitrile $(90 / 10, \mathrm{v} / \mathrm{v})$ at a flow rate of $1.0 \mathrm{~mL} \mathrm{~min}^{-1}$ on an Inertsil ODS-3V C18 column $(4.6 \mathrm{~mm} \times 250 \mathrm{~mm}, 5.0$ $\mu \mathrm{m})$ that was kept at $30{ }^{\circ} \mathrm{C}$. The analysis was conducted at $30{ }^{\circ} \mathrm{C}$, which offers a lot of advantages such as good chromatographic peak shape, enhanced column efficiency, and low-column pressure, in addition to being economic. The eluate was monitored using a UV detector set at $323 \mathrm{~nm}$. Under the chromatographic conditions FVP were eluted at retention times 7.696. The tablet solution was analyzed for $60 \mathrm{~min}$ to ensure that there were no matrix components

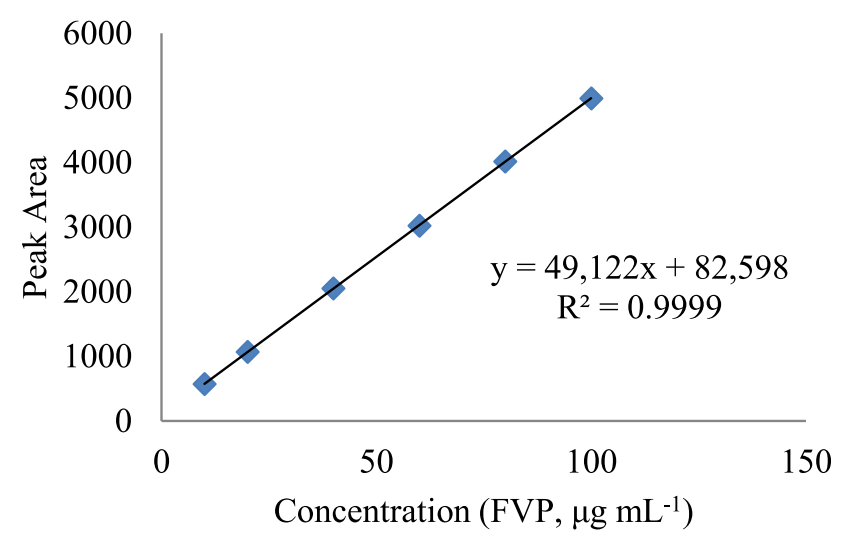

Fig. 3. Calibration curve $(\lambda: 323 \mathrm{~nm})$ 
Table 1. Statistical data (calibration curve, FVP)

\begin{tabular}{lc}
\hline Parameter & Value \\
\hline Linearity range $\left(\mu \mathrm{g} \mathrm{mL}^{-1}\right)$ & $10-100$ \\
Slope & 49.122 \\
Intercept & 82.598 \\
Correlation coefficient & 0.9999 \\
Lack of fit & \\
$F$ & 2.90 \\
$P$ & 0.0516 \\
SE of intercept & 6.9024 \\
SD of intercept & 15.4340 \\
LOD/LOQ $\left(\mu \mathrm{g} \mathrm{mL} \mathrm{mL}^{-1}\right)$ & $1.20 / 3.60$ \\
\hline
\end{tabular}

remaining in the column for much longer under the specified conditions. However, continuing the analysis after 15 min will increase both the analysis time and the cost. Overlapping peaks were not observed to overlap in samples from sample analyses injected into the system consecutively with 15 min of analysis time. Due to all these, the analysis time was determined as $15 \mathrm{~min}$.

\section{METHOD VALIDATION}

\section{Linearity}

The stock standard solution of FVP was diluted appropriately with deionized water to obtain standard solutions within the concentration range of $10-100 \mu \mathrm{g} \mathrm{mL}{ }^{-1}$. Each standard solution was injected three times into the HPLC system under the above-mentioned chromatographic working conditions. Linearity of the proposed method has been estimated at 6 concentration levels in the range of 10 $100 \mu \mathrm{g} \mathrm{mL}^{-1}$ by regression analysis. The calibration curve was developed by plotting average peak area versus standard

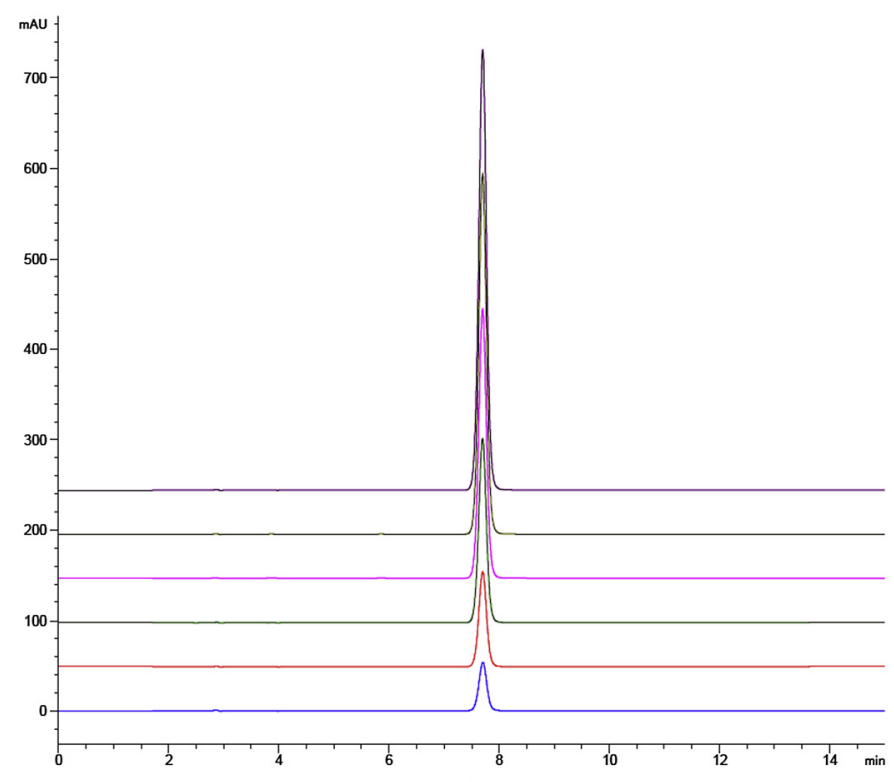

A

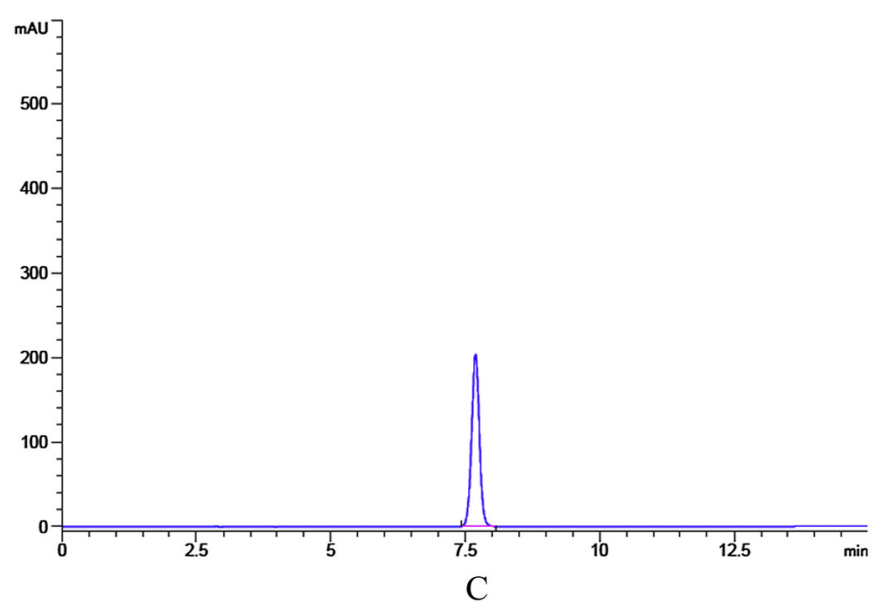

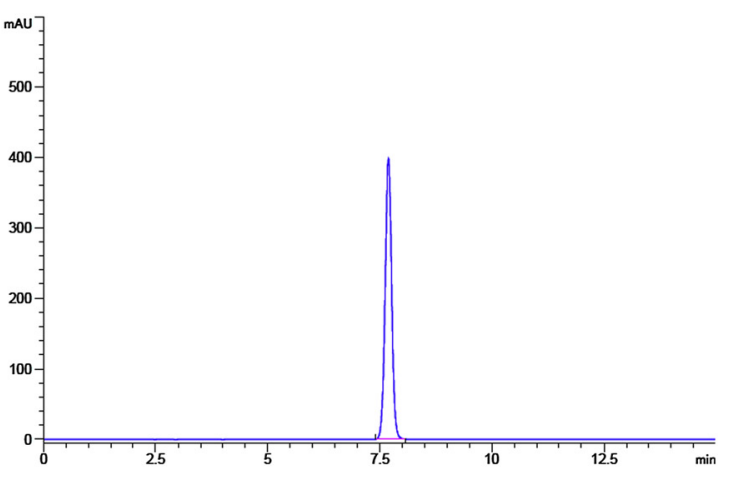

B

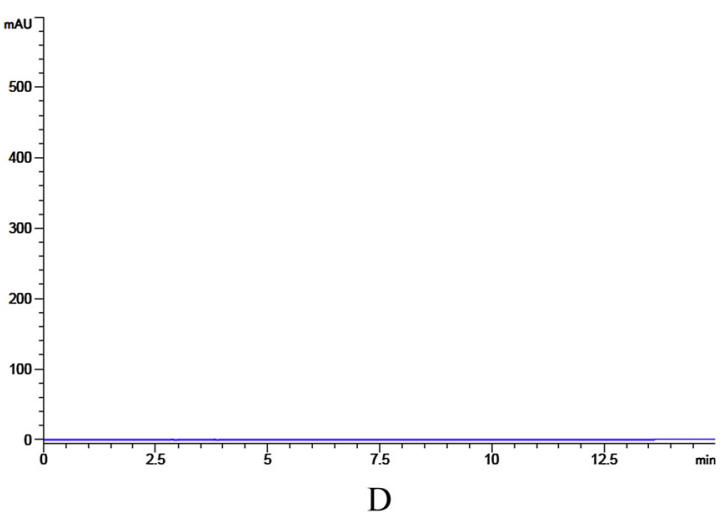

Fig. 4. (A) Overlay chromatogram (standard solutions, $10-100 \mu \mathrm{g} \mathrm{mL} L^{-1}, \lambda: 323 \mathrm{~nm}$ ). (B) Chromatogram (standard solution, $80 \mu \mathrm{g} \mathrm{mL}{ }^{-1}, \lambda$ : $323 \mathrm{~nm}$ ). (C) Chromatogram (sample solution, $40 \mu \mathrm{g} \mathrm{mL}-1, \lambda: 323 \mathrm{~nm}$ ). (D) Chromatogram (Blank solution, $\lambda: 323 \mathrm{~nm}$ ) 
Table 2. Precision data

\begin{tabular}{|c|c|c|c|c|c|c|}
\hline \multirow[b]{2}{*}{$\begin{array}{l}\text { Std. conc. } \mu \mathrm{g} \\
\mathrm{mL}^{-1}\end{array}$} & \multicolumn{3}{|c|}{ Intraday precision } & \multicolumn{3}{|c|}{ Interday precision } \\
\hline & $\begin{array}{l}\text { Found conc. } \\
\qquad(6) \\
\left(\mu \mathrm{g} \mathrm{mL} L^{-1}\right)\end{array}$ & $\begin{array}{c}\text { Peak area RSD } \\
(\%)\end{array}$ & $\begin{array}{c}\text { Retention time RSD } \\
(\%)\end{array}$ & $\begin{array}{l}\text { Found conc. } \\
\qquad(6) \\
\left(\mu \mathrm{g} \mathrm{mL}{ }^{-1}\right)\end{array}$ & $\begin{array}{c}\text { Peak area RSD } \\
(\%)\end{array}$ & $\begin{array}{c}\text { Retention time RSD } \\
(\%)\end{array}$ \\
\hline 20 & 20.02 & 0.178 & 0.015 & 19.92 & 0.195 & 0.034 \\
\hline 40 & 40.35 & 0.066 & 0.004 & 40.08 & 0.082 & 0.012 \\
\hline 60 & 60.24 & 0.041 & 0.002 & 60.10 & 0.064 & 0.025 \\
\hline
\end{tabular}

Table 3. Recovery data

\begin{tabular}{|c|c|c|c|c|c|c|}
\hline Spiked level (\%) & Amount added $\left(\mu \mathrm{g} \mathrm{mL}^{-1}\right)$ & Amount recovered $\left(\mu \mathrm{g} \mathrm{mL}^{-1}\right)$ & Recovery (\%) & Average (\%) & SD & $\begin{array}{c}\text { RSD } \\
(\%)\end{array}$ \\
\hline \multirow[t]{3}{*}{80} & 32 & 31.78 & 99.31 & 99.96 & 0.157 & 0.157 \\
\hline & 32 & 31.74 & 99.19 & & & \\
\hline & 32 & 31.84 & 99.50 & & & \\
\hline \multirow[t]{3}{*}{100} & 40 & 39.79 & 99.48 & 99.93 & 0.180 & 0.180 \\
\hline & 40 & 39.75 & 99.38 & & & \\
\hline & 40 & 39.89 & 99.73 & & & \\
\hline \multirow[t]{3}{*}{120} & 48 & 48.02 & 100.04 & 99.75 & 0.125 & 0.125 \\
\hline & 48 & 48.08 & 100.17 & & & \\
\hline & 48 & 47.96 & 99.92 & & & \\
\hline
\end{tabular}

concentration (Fig. 3). The correlation coefficient, slope, and intercept of the regression line were determined using the least squares method. The relation between mean peak area $Y(n=3)$ and concentration, $X$ expressed by equation $Y=a$ $+b X$, was linear. Values of slope, intercept, and correlation coefficient $(r)$ were $49.122,82.598$ and 0.9999 , respectively as shown in Table 1. Lack of fit test was performed to evaluate linearity. In the Lack of fit test, $P$ value $(0.0516)$ greater than 0.05 indicates that the data satisfies the linearity condition. Overlay chromatogram of FVP standard solutions (10-100 $\mu \mathrm{g} \mathrm{mL}^{-1}$ ) was demonstrated in Fig. 4A.

\section{Specificity/selectivity}

The chromatogram of FVP standard solution has been given in Fig. 4B. There is only one peak at the retention time of $7.696 \mathrm{~min}$. The chromatogram of the tablet solution has been given in Fig. 4C. There is only one peak at the retention time of $7.696 \mathrm{~min}$ in this chromatograme. There are no other peaks caused by excipients and additives in this chromatograme. The chromatogram of the mobile phase has also given in Fig. 4D. There are no other peaks caused by contents of the mobile phase in this chromatograme. This indicates that the analytical method is specific. The parameters retention time and tailing factor were calculated in order to prove that the method chosen was specific. Retention time, theoretical plate number, and peak tailing factor values were $7.696,13798$, and 0.920 , respectively. All of the values were within the accepted level.

\section{Precision}

Precision study was performed by injecting six times of standard solution at three different concentrations, 20, 40, and $60 \mu \mathrm{g} \mathrm{mL} L^{-1}$ on the same day and three consecutive days. The precision data were given in Table 2. All RSD values for retention time and peak area for selected FVP concentrations were less than 0.5 and $2.0 \%$, respectively. In this case, the method is precise and can be used for our intended purpose.

\section{Accuracy study}

A known quantity of standard solution has been added to the sample solutions previously analyzed at three different levels $(80 \%, 100 \%$ and 120\%). The amount recovered for favipiravir has been calculated for three concentration. The recovery data were summarized in Table 3. Percent RSD values for all analyses were less than $2 \%$ indicating that excipients found in pharmaceutical formulations do not interfere and analytical method is very accurate.

Table 4. Robustness data

\begin{tabular}{|c|c|c|c|c|}
\hline Condition & Variation & Assay(\%) & SD & $\mathrm{RSD}(\%)$ \\
\hline \multirow{2}{*}{$\begin{array}{l}\text { Mobile phase flow } \\
\text { rate }(1.00 \mathrm{~mL} \\
\left.\min ^{-1}\right)\end{array}$} & $\begin{array}{c}0.90 \mathrm{~mL} \\
\min ^{-1}\end{array}$ & 99.86 & 0.60 & 0.60 \\
\hline & $\begin{array}{c}1.10 \mathrm{~mL} \\
\mathrm{~min}^{-1}\end{array}$ & 99.94 & 0.62 & 0.62 \\
\hline \multirow{2}{*}{$\begin{array}{l}\text { Acetonitrile ratio } \\
\text { in mobile phase } \\
(10 \%)\end{array}$} & $9 \%$ & 100.12 & 0.67 & 0.67 \\
\hline & $11 \%$ & 99.96 & 0.71 & 0.71 \\
\hline \multirow{2}{*}{$\begin{array}{l}\text { Column } \\
\text { temperature } \\
\left(30^{\circ} \mathrm{C}\right)\end{array}$} & $28{ }^{\circ} \mathrm{C}$ & 99.96 & 0.34 & 0.34 \\
\hline & $32{ }^{\circ} \mathrm{C}$ & 100.05 & 0.32 & 0.32 \\
\hline
\end{tabular}


Table 5. Standard solution stability $\left(40 \mu \mathrm{g} \mathrm{mL}^{-1}\right)$

\begin{tabular}{|c|c|c|c|c|c|c|c|c|}
\hline Time (h) & Peak area & Mean & SD & RSD (\%) & Retention time (min) & Mean & SD & $\begin{array}{l}\text { RSD } \\
(\%)\end{array}$ \\
\hline \multirow[t]{3}{*}{8} & 2013.5 & 2019.7 & 5.5 & 0.275 & 7.594 & 7.596 & 0.009 & 0.115 \\
\hline & 2021.3 & & & & 7.606 & & & \\
\hline & 2024.2 & & & & 7.589 & & & \\
\hline \multirow[t]{3}{*}{16} & 2025.6 & 2020.0 & 5.2 & 0.257 & 7.597 & 7.599 & 0.015 & 0.192 \\
\hline & 2019.2 & & & & 7.614 & & & \\
\hline & 2015.3 & & & & 7.585 & & & \\
\hline \multirow[t]{3}{*}{24} & 2012.2 & 2018.1 & 6.5 & 0.323 & 7.610 & 7.597 & 0.011 & 0.150 \\
\hline & 2025.1 & & & & 7.588 & & & \\
\hline & 2017.1 & & & & 7.594 & & & \\
\hline
\end{tabular}

Table 6. Method application results

\begin{tabular}{lccc}
\hline Formulation & $\begin{array}{c}\text { Label claim } \\
(\mathrm{mg})\end{array}$ & $\begin{array}{c}\text { Amount of drug } \\
(\mathrm{mg})\end{array}$ & $\begin{array}{c}\% \text { Assay } \pm \\
\text { SD }\end{array}$ \\
\hline $\begin{array}{l}\text { Favicovir } \\
\text { tablet }\end{array}$ & 200 & 200.35 & $100.18 \pm 0.38$ \\
\hline
\end{tabular}

\section{Robustness}

The results showed that the change in flow rate and mobile phase concentration had little effect on the chromatographic behavior of FVP. The small change in the mobile phase flow rate and acetonitrile content have a small impact on the retention time of FVP. The change in the column temperature did not have a significant effect on the method. The results of this study, expressed as \% RSD, were presented in Table 4.

\section{Solution stability}

The stability of sample and standard solutions was monitored over a $24 \mathrm{~h}$ period. For this, standard and sample solutions were injected into the system at $8 \mathrm{~h}$ periods, and the peak area and retention time were evaluated. No changes in standard concentrations have been observed over a period of $24 \mathrm{~h}$. The $\%$ RSD for peak area $(n=3)$ was $0.275 \%$ and the value for retention time $(n=3)$ was $0.12 \%$ for standard solution. The results have been demonstrated in Table 5. No major changes in active ingredient concentration have also been found in the tablet solution.

\section{Application of the method to the marketed tablets}

The developed and validated method has been applied successfully for determination of FVP in pharmaceutical formulations. The result of assay of the marketed tablet of favipiravir is shown in Table 6. The results obtained are closely related to the amount indicated on the labels of the tablets. This shows that the method for content evaluation is useful.

\section{CONCLUSIONS}

A very quick, cost-effective, precise and accurate HPLC method for the determination of FVP has been developed and validated in compliance with ICH guidance Q2. Besides the short run time (15 min), retention time (7.696) and flow

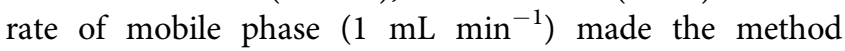
attractive because these features save analysis time and cost. Potassium dihydrogen phosphate, used as a general purpose buffer, has many interesting properties. The most important of these features are good buffering capacity in the selected $\mathrm{pH}$ range, easy availability, low toxicity and cost, and greatly improved separation ability without colon degradation. In short, this method is sensitive, selective, reproducible and rapid for favipiravir in bulk and tablets. The accuracy and precision are within reasonable limits, the maximum of quantification is as small as $3.60 \mu \mathrm{g} \mathrm{mL}^{-1}$ and finally analytical method is reliable and robust.

\section{ACKNOWLEDGEMENTS}

The author would like to thank to Atabay Pharmaceuticals and Fine Chemicals Inc. for providing pure drug reference sample and supporting this work.

\section{REFERENCES}

1. Saber-Ayad, M.; Saleh, M. A.; Abu-Gharbieh, E. The rationale for potential pharmacotherapy of COVID-19. Pharmaceuticals 2020, 13, 96-105.

2. Sohrabi, C., Alsafi, Z.; O’Neill, N.; Khan, M.; Kerwan, A.; Al-Jabir, A.; et al. World Health Organization declares global emergency: A review of the 2019 novel coronavirus (COVID-19), Int. J. Surg. 2020, 76, 71-6.

3. Zhu, R. F.; Gao, R. I.; Robert, S. H.; Gao, J. P.; Yang, S. G.; Zhu, C. Systematic review of the registered clinical trials of coronavirus diseases 2019 (COVID-19), J. Transl. Med. 2020, 18, 274-9.

4. Prajapat, M.; Sarma, P.; Shekhar, N.; Avti, P.; Sinha, S.; Kaur, H.; et al. Drug targets for corona virus: A systematic review. Indian J. Pharm. 2020, 52(1), 56-63.

5. Dong, L.; Hu, S.; Gao, J. Discovering drugs to treat coronavirus disease 2019 (COVID-19). Drug Discov. Ther. 2020, 14(1), 58-60.

6. De Clercq, E. New nucleoside analogues for the treatment of hemorrhagic fever virus infections. Chem.-Asian J. 2019, 14(22), 3962-8. 
7. Delang, L.; Abdelnabi, R.; Neyts, J. Favipiravir as a potential countermeasure against neglected and emerging RNA viruses. Antiviral Res. 2018, 153, 85-94.

8. Chen, C.; Huang, J.; Cheng, Z.; Wu, J.; Chen, S.; Zhang, Y.; et al. Favipiravir versus arbidol for COVID-19: A randomized clinical trial, medRxiv 2020, 3, 17-20.

9. China patent (CN104914185B). A kind of Favipiravir has the HPLC assay method of related substance. 21.09.2016.
10. China patent (CN104914185A). HPLC method for measuring related substances in Favipiravir. 16.09.2015.

11. ICH. (2005). Q2 (R1), harmonized tripartite guideline, validation of analytical procedures: text and methodology, In Proceedings of the International Conference on Harmonization of Technical Requirements for Registration of Pharmaceuticals for Human Use.

12. Center for Drug Evaluation and Research (CDER). (1994). Reviewer Guidance: Validation of Chromatographic Methods. CMC, 3. 